\title{
DEPLOYMENT OF CONSTRUCTION ROBOTS APPLYING THE INFORMATION TECHNOLOGY AND NETWORK SYSTEM
}

\author{
SHIGEO KITAHARA \\ MACHINERY \& MATERIALS DEPT. \\ CIVIL ENGINEERING DIVISION \\ KUMAGAI GUMI CO.,LTD \\ 2-1 TSUKUDO-CHO \\ SHINJUKU-KU,TOKYO 162-8557 \\ JAPAN \\ Email:skitahar@ku.kumagaigumi.co.jp
}

\author{
YOSHIDA TAKASHI \\ MACHINERY \& ENGINEERING DEPT. \\ NISHIMATSU CONSTRUCTION CO.,LTD \\ 1-20-10 TORANOMON \\ MIMATO-KU ,TOKYO 105-8401 \\ JAPAN \\ Email:takashi_yoshida@nishimatsu.co.jp
}

\begin{abstract}
:
The future points to the application of IT to the construction robot for the overall processes of civil engineering work from the planning and design stages to the maintenance management. The Civil Engineering Technology Subcommittee in charge of civil engineering work field in the Robotics Committee in Construction of the Japan Society of Civil Engineers has reviewed the current situations and the future perspective as well as issues on the observational construction method and the unmanned construction method using a construction robot, with an attempt to view the extensive perspective design. The subcommittee investigated and studied the prospects and challenges in the IT-using construction robot in the civil engineering work field in terms of information technologies using information networks into the construction robot. This report asserts that to attain advancement of use of the construction robot in the civil engineering field, it is essential to standardize the machinery and communication systems and depict a grand design of new information services under the trend toward standardization of information use systems in order to carry forward an enhancement in their inter-convenience through information integration from the planning and designing to maintenance management phases of the civil work.
\end{abstract}

Keywords: construction robots, future perspective, Information Technology, civil engineering work

\section{Introduction}

The Civil Engineering Technology Subcommittee in charge of the civil engineering field in the Robotics in Construction Subcommittee of the Japan Society of Civil Engineers has reviewed the current situation and the future perspective as well as tasks for the future regarding the application of network and information technology to construction robots. The review considered measures to utilize IT in all processes of civil engineering construction throughout the life cycle, from the planning and design stage through to maintenance management, as well as automation technology and unmanned construction methods using construction robots, in an attempt to depict an extensive grand design.

\section{Current situation and tasks for the application of IT} to automated construction in the civil engineering field

In 1999, the estimated number of construction machinery had increased by about $40 \%$ compared with 10 years previously, from which it can be said that mechanization is being positively embraced in the civil engineering construction field. In addition, automated construction in the civil engineering construction field was promoted for the restoration construction work from natural disasters for which there was a danger of secondary disasters, such as Mount Unzen-Fugen Dake and Mount Usu. On the other hand, in general construction also, automation of vibratory rollers and large dump trucks was promoted, and many examples of their application to construction of expressways and new airports have been seen. In the future it is expected that the utilization of IT in response to shortages of skilled operatives and simplification of operations will result in work efficiency, cost reduction, and improvement in quality.

2.1 Current situation regarding sensing technology in the civil engineering construction field

In the civil engineering construction field, the main technologies for achieving automated construction can be broadly divided into hydraulic controls for automating construction machinery itself and sensing technology for acquiring positional information, including 3-dimensional information. The main sensing technologies that have been applied to automated construction include the following:

(1) Rotating lasers (rotating laser levels)

(2) Automatic tracking type total station

(3) GPS (Global Positioning System)

(4) Laser scanner

(5) 3D cameras (stereo cameras)

(6) GIS (Geographic Information System)

2.2 Examples of application of automated construction

As an example of Government activities in automated construction in the civil engineering field, from 1999 to 2000 the Kanto Regional Development Bureau of the 
Ministry of Land, Infrastructure and Transport carried out a construction test on a method of controlling consolidation of an embankment using a total station. Based on the results of this test, in March 2001 the requirements for embankment construction control (draft) "Embankment Consolidation System" was prepared, and the new control method using an automatic tracking type total station has been added as a "new approved construction method" in respect to the existing construction control method. On the other hand, examples of the response of the private sector include not only the introduction of large scale construction machinery for reducing the cost of construction, but also to ensure permanent embankment stability and reduce residual settlement, systems for gathering and storing 3-dimensional tracking information for consolidation machinery using GPS or automatic tracking total stations have been used for the land reclamation works for the Chubu International Airport and the Kansai Airport Phase II land reclamation works.

\subsection{Future developments}

In response to the automation of construction, all the manufacturers are providing compatible machinery in their lineup. In addition, rental companies have compatible construction machinery, etc., so the supply system is being established. On the other hand, as a movement on the government side the Ministry of Land, Infrastructure and Transport has already established a policy for the fully fledged introduction of automated construction to public works, and from 2002 automated construction has been used in construction of general erosion and landslide control works, and construction is being carried out in areas that formerly were difficult for construction. Also, technical development for customizing many types of construction machinery into unmanned machinery is proceeding.

Since unmanned construction was adopted for the disaster recovery work for Mount Unzen-Fugen Dake and Mount Usu, automated construction in civil engineering has reached the practical implementation level technically. Therefore, there are many unsolved problems such as machinery costs, construction efficiency, and wireless technology, etc., so it is necessary to proceed with solving these remaining problems.

\section{Present situation and tasks for the application of IT to unmanned construction for disaster prevention}

Unmanned construction may be defined as "construction methods in which construction can be carried out without personnel in the construction area, by using construction machinery equipped with a remote operation function or other advanced operation control system or imaging devices, etc." Therefore, the restoration works for Mount Unzen-Fugen Dake, Mount Usu, and other volcanic eruptions and dam construction at Jinnosuke Valley, etc., as well as pneumatic caisson construction and other constructions are classified as unmanned construction if they are carried out by remote unmanned operation.
In this section, the application of IT to unmanned construction, in particular recent volcanic eruption recovery work and protective embankment construction, is described.

\subsection{Present situation of unmanned construction for disaster} prevention works

Unmanned construction is adopted in cases where safety of the work place cannot be ensured but nonetheless construction is necessary. The "Guidebook for unmanned construction during emergencies", edited by the Advanced Construction Technology Center, postulates the following as cases where safety cannot be ensured:

(1) When volcanic activity has not ceased

(2) When the causes and mechanisms of a disaster are not clear, and prediction and prevention are difficult

(3) When the causes of a disaster exist

(4) When there is the possibility that work could damage the stability of, for example, slopes

(5) Others

\subsection{Examples of application to disaster restoration works}

Table 1 Examples of technologies introduced to unmanned construction

\begin{tabular}{|c|c|c|}
\hline $\begin{array}{l}\text { New technology introduced to } \\
\text { unmanned construction }\end{array}$ & $\begin{array}{l}\text { Characteristics of the } \\
\text { technology }\end{array}$ & $\begin{array}{l}\text { Example of commencement } \\
\text { of introduction }\end{array}$ \\
\hline $\begin{array}{l}\text { Remote operation of } \\
\text { construction equipment } \\
\text { within the visual range }\end{array}$ & $\begin{array}{l}\text { Up to } 50 \mathrm{~m} \text {, one signal per } \\
\text { machine }\end{array}$ & $\begin{array}{l}\text { 1940 , steelmaking plant, } \\
\text { mines }\end{array}$ \\
\hline $\begin{array}{l}\text { Remote operation of } \\
\text { construction equipment with } \\
\text { imaging support (including } \\
\text { trial of 3-dimensional } \\
\text { imaging) }\end{array}$ & $\begin{array}{l}\text { If the site and the operation } \\
\text { room are more than } 50 \mathrm{~m} \\
\text { apart, imaging from the site is } \\
\text { necessary }\end{array}$ & Introduced at Unzen \\
\hline $\begin{array}{l}\text { Automatic tracking of } \\
\text { antenna mounted on moving } \\
\text { body }\end{array}$ & $\begin{array}{l}\text { For } 50 \mathrm{GHz} \text { simple wireless } \\
\text { system (Note } 1 \text { ) }\end{array}$ & There are three formats \\
\hline $\begin{array}{l}\text { Very long distances using a } \\
\text { relay }\end{array}$ & $\begin{array}{l}\text { Cable, wireless systems (Note } \\
\text { 2) }\end{array}$ & $\begin{array}{l}\text { Unzen, Japan Defense } \\
\text { Agency, Usu }\end{array}$ \\
\hline $\begin{array}{l}\text { Specially permitted high } \\
\text { output radio wave }\end{array}$ & $\begin{array}{l}1,2,5 \mathrm{~W} \text {, specially permitted } \\
\text { for disasters }\end{array}$ & Unzen, Usu \\
\hline $\begin{array}{l}\text { Multiplexed transmission of } \\
\text { several machine's } \\
\text { information }\end{array}$ & $\begin{array}{l}\text { Using a cable relay an } 50 \mathrm{GHz} \\
\text { radio waves }\end{array}$ & Introduced at Unzen \\
\hline $\begin{array}{l}\text { Machine operating status } \\
\text { monitoring system }\end{array}$ & $\begin{array}{l}\text { Status monitoring system for } \\
\text { machines }\end{array}$ & Introduced at Unzen \\
\hline $\begin{array}{l}\text { Unmounted type construction } \\
\text { machinery }\end{array}$ & $\begin{array}{l}\text { Dedicated remote operation } \\
\text { machine with no driver's seat }\end{array}$ & Compaction of dam concrete \\
\hline $\begin{array}{l}\text { Remote inspection system for } \\
\text { disaster site status }\end{array}$ & $\begin{array}{l}\text { Relay, ground pressure and } \\
\text { temperature distribution } \\
\text { measurement, taking samples, } \\
\text { etc. }\end{array}$ & $\begin{array}{l}\text { Hokkaido Regional } \\
\text { Development Bureau, MHI }\end{array}$ \\
\hline $\begin{array}{l}\text { Addition of GPS position } \\
\text { information }\end{array}$ & $\begin{array}{l}\text { No. of times of surface } \\
\text { compaction, surface } \\
\text { compaction range, } \\
\text { measurement of settlement }\end{array}$ & $\begin{array}{l}\text { By unmanned machine at } \\
\text { Unzen and elsewhere }\end{array}$ \\
\hline $\begin{array}{l}\text { Work device and distance } \\
\text { measurement }\end{array}$ & $\begin{array}{l}\text { Objective was optimum } \\
\text { control of spraying operations }\end{array}$ & Sabo Works at Mount Fuji \\
\hline $\begin{array}{l}\text { Operation of machines with } \\
\text { different specifications with } \\
\text { the same transmitter }\end{array}$ & $\begin{array}{l}\text { Common exchange } \\
\text { (transmission protocol } \\
\text { switching) }\end{array}$ & $\begin{array}{l}\text { Hokuriku Technical Center, } \\
\text { and others }\end{array}$ \\
\hline Robo-Q & $\begin{array}{l}\text { Remote operation device } \\
\text { using an air actuator }\end{array}$ & Kyushu Gijutsu, Fujita \\
\hline ALT & $\begin{array}{l}\text { Remote operation device } \\
\text { using an electromagnetic } \\
\text { actuator }\end{array}$ & Nishio Rental, Shimizu \\
\hline $\begin{array}{l}\text { All data two-way multiplexed } \\
\text { transmission }\end{array}$ & $\begin{array}{l}\text { 2.4GHz SS wave and machine } \\
\text { and camera control + image }\end{array}$ & Kanto Technical Center \\
\hline $\begin{array}{l}\text { Data transmission on a } \\
\text { wireless LAN }\end{array}$ & $\begin{array}{l}\text { Transmission of control and } \\
\text { image data by internet } \\
\text { protocol }\end{array}$ & $\begin{array}{l}\text { Penta Ocean qualification } \\
\text { acquisition test }\end{array}$ \\
\hline $\begin{array}{l}\text { Construction using a } \\
\text { combination of cable and } \\
\text { wireless LAN }\end{array}$ & $\begin{array}{l}\text { Expansion of the transmission } \\
\text { area in a long distance site } \\
\text { with complex topography }\end{array}$ & $\begin{array}{l}\text { Tonegawa Sogo Sabo } \\
\text { Tanisawa Gawa }\end{array}$ \\
\hline
\end{tabular}


Research into new types of unmanned construction, work mechanisms, and sensing systems in response to the many construction situations encountered on each construction site has been vigorously carried out. Examples of the introduction of technologies to unmanned construction are shown in Table 1.

\section{Future perspective on construction robots using IT and tasks for the future}

4.1 Examples of civil engineering automated construction using IT

In the civil engineering construction field, automation technology has been applied mainly to large scale construction work, in particular large scale construction machinery and transport machinery. Construction equipment position and surrounding information sensing technology of construction equipment (automatic tracking total stations, GPS, laser scanners, etc.) has been applied. In the future it is expected that progress in information sharing by the promotion of IT will lead to work efficiency, cost reduction, and improvements in quality.

In the disaster prevention construction field, a typical automation technology is unmanned construction technology for construction machinery. The development of construction methods for unmanned construction machinery and the introduction of communication technology, construction equipment operation technology, measurement technology, etc., along with remote operation is being actively carried out.

In addition, due to labor shortages caused by the dwindling birthrate and aging population and the desirability of relieving arduous work, in the maintenance management field, dedicated robots are being introduced to carry out such work (painting robots to repaint bridges, automatic steering type rotary snow removal vehicles, etc.). Tasks for the future include increasing the amount of automation and improving the work accuracy, etc.

\subsection{Information technology associated with construction robots}

Since fiscal year 1996, the Ministry of Land, Infrastructure and Transport has been undertaking Construction Continuous Acquisition and Life-cycle Support/Electronic Commerce (CALS/EC) with the aim of improving the productivity of public works, ensuring quality, and reducing costs by sharing electronic information between business processes. In March 2006 the "Ministry of Land, Infrastructure and Commerce CALS/EC Action Program 2005"1) was adopted, indicating a 3-year action plan until FY2007. In CALS/EC, the focus is on "information sharing and linking" and "business process improvement" using electronic information, based on the digitization of all types of conventional information. Here, the aim is to achieve practical results in a short period of time; specifically various targets are given for the following examples:

(1) Improvement of design and construction control by promoting the use of 3-dimensional information
(2) Promotion of information exchange, sharing, and linking by information model control

(3) Cost reduction by automating calculation of quantities from CAD

(4) Improvement in construction control, supervision and inspection by exchange and sharing of information during construction

As a related item, in ISO/TC127 (WG2), a draft ISO standard (ISO15143) has been prepared for the method of preparing construction information data exchange standards $^{2)}$ at the construction stage. This is fundamental technology to promote information flow at the construction stage among construction machinery and construction robots by providing the information model and data dictionary. Also, in a related undertaking, the method and system of registering and storing the model and dictionary are being investigated. ${ }^{3)}$

ISO TC127 undertakes standardization for information exchange between machinery in the civil engineering construction field, and has reported on the concept of standardization, the function of standards for data exchange, and the preparation of standards.

4.3 Services and usage information in automation of civil engineering construction (Committee member Ueishi)

4.3.1 Current status of information usage in civil engineering construction

Most of the attempts at automation in civil engineering construction to date have been large scale projects, and the systems used have been proprietary systems developed by manufacturers. Also, it is necessary to prepare the information used by heavy equipment for each project, so automation is not easy to use on any site, and so at present it is only used on those sites where it is cost effective.

Problems with information usage include

(1) Problems with usage of design information

(2) Problems with the preparation of construction documents

(3) Problems with information usage in construction by machines.

But the cause may be that electronic data at the design stage is 2-dimensional and is not reused, whereas information obtained during construction (3-dimensional) is not sufficiently reused. Therefore, what is necessary is not just the efficiency due to mechanized construction that has been the aim of IT in construction to date, but to achieve improvements in services and work (BPR) across all the processes by using the 3-dimensional spatial information.

4.3.2 Services achieved by utilizing 3-dimensional spatial information

Figure 2 shows information usage in all the processes of civil engineering construction from project planning, surveying, design, construction, maintenance management, and renewal. In this diagram, services such as quality control, equipment control, supervision and inspection, finished shape control, safety/environmental, etc., can be achieved by the particularly large volume of information 
handled during construction. To achieve an information flow that allows reuse of information, it is necessary that there be no obstacles to flow from upstream to downstream, to achieve information use from planning to renewal. The main information that needs to flow includes design information and finished shape information, and by effectively using it as 3-dimensional data it is considered that various benefits will be achieved. Furthermore, in order to extract the necessary information at each stage of construction, sorting based on information analysis and information modeling is necessary at various stages.

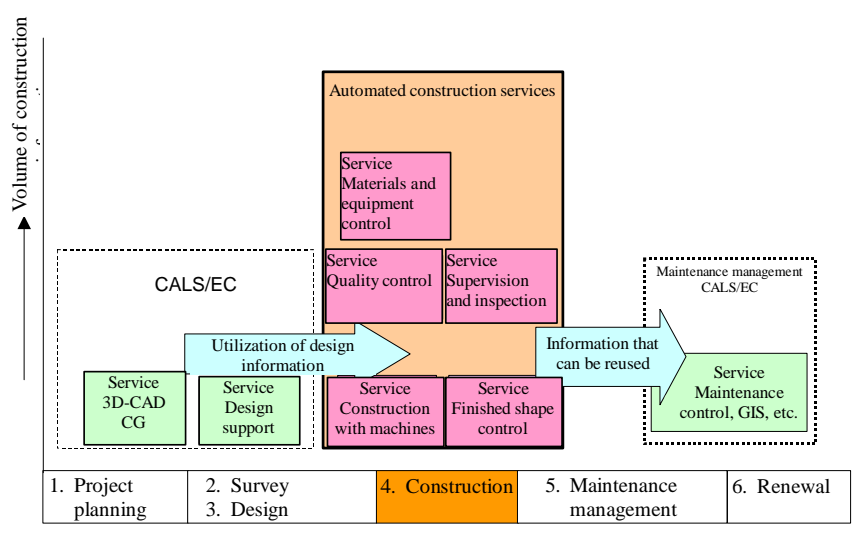

Fig. 2 Construction processes and information usage (image)

Examples of envisaged services include the following:

(1) Simplify comparison of finished shape and design shape

(2) Achievement of area-wide quality control

(3) Preparation of heavy equipment control data using design data

(4) Speeding up of site work when there is a design change

(5) Efficiency of supervision and inspection

(6) Efficiency of control of materials and equipment

(7) Efficiency of control of machinery

\subsubsection{Tasks for utilization of information}

To achieve the above services, it is necessary to promote information use between construction processes and between construction machinery systems, for which purpose the following tasks have been identified.

In identifying the tasks, analysis has been carried out based on modeling of robot construction (function and information analysis, scenarios).

1) Promotion of use of 3-dimensional modeling

(1) Establishment of construction control model

(2) Promotion of the use of 3-dimensional design information

(3) Promotion of use of finished shape information on construction sites

2) Tasks for creating construction systems

(1) To clarify the required information system

(2) Development of element technology to determine the status of construction
3) Man-machine cooperation type operation controls

(1) Thinking regarding allocation of roles between man and machine

(2) Exchange of information between man and machine

(3) Tools for information exchange between man and machine

4) The necessity of information standardization

4.4 Future perspective tasks for automation of civil engineering construction

4.4.1 Future perspective on civil engineering construction

Regarding the fields of application of automation technology, it is considered that the civil engineering construction field is one of the types of construction that is driven by automation of construction. In the futurem utilization will spread to sites with contaminated soil, which has become a big problem for environmental pollution, in particular for excavation and removal of soil contaminated with dioxins, PCBs (polychlorinated biphenyls), or radioactive materials.

On the hardware side, in addition to construction machinery, automation of transport machinery such as dump trucks and crawler carriers, etc., is planned. In addition, in the future, it is expected that crane type lifting equipment will be automated and unmanned. Also, the technology is being developed to use conventional construction machinery as unmanned construction machinery by installing an automatic operation unit on the conventional machinery on site.

In the future, it is likely that the scope of association and use of data will broadened, such as the use of CAD and other design data in the construction stage, and the use of information gathered by machinery during construction for quality control and control of finished shape.

4.4.2 Problems for the future for automation of civil engineering construction

Sharing and standardization of construction information is necessary, and networking is simplified by information standardization. For example, for positional information on site, each separate system can access the data storage computer to download, overwrite, and store information, and by separating the part that can be shared for each system (consolidation automation system, laying system, and other independent systems) the system can be made more sprightly.

Also, a very important task for the future is providing an environment in which 3-dimensional construction information can be shared and used from the upstream design stage through the construction stage to the downstream maintenance and inspection stage; standardization of this usage information is a big task.

The development of technology for data communication between construction sites, the application of wireless LANs, the development and implementation of high speed mobile communication systems, and the easing of regulations on wireless communication environment for limited periods of time are tasks for the future. 
4.4.3 Increasing the penetration of information technology in the civil engineering construction field

One point for the employer and contractor regarding creating the new system is determining new specific quality evaluation criteria based on construction and construction control information obtained by the automated construction system. In this way, the responsibilities of the contractor to the employer for assurance of quality is clarified, and at the same time efficient construction control can be guaranteed by submitting the construction control information obtained.

Also, for quality assurance, by standardizing machine performance and control information, it is necessary that the performance standards and control methods of the employer and contractor are integrated as regards information technology.

In order to increase the penetration of information technology, new schemes are needed to replace the existing control schemes, and it is necessary for employers and contractors to provide environments for construction and construction control. If this is achieved, the contractor will assume greater self-responsibility for construction than before, but efficiency and cost reduction effects will be obtained. On the other hand, for the employer it is expected that the burden of quality control responsibility will be lightened, so that the benefits of information technology can be obtained by both.

\section{Conclusion}

A study has been carried out on the future perspective and tasks for the future for construction robots using IT in the civil engineering construction field, from the viewpoint of application of IT using networks, whose development continues with the rapid revolution in electronic information technology in recent years, to construction robots.

As shown in sections 2 through 4, in order to raise the utilization of construction robots in the civil engineering construction field, it is vital that in the flow of standardization of information usage, standardization of communication systems with machines and grand designs through new information services are steadily created, and that mutual convenience is improved by integrating information from the planning and design stages through to the maintenance management stage.

This report has been prepared as a report on the activities of the Civil Engineering Technology Subcommittee of the Robotics in Construction Subcommittee of the Japan Society of Civil Engineers, so it has been jointly written by the members of the subcommittee.

\section{REFERENCES}

[1] Ministry of Land, Infrastructure and Transport: Ministry of Land, Infrastructure and Transport CALS/EC Action Program 2005, http://www.mlit.go.jp/kisha/kisha06/13/130315_.html, (March 15, 2006)
[2] Atsuro Oyama, Hiroshi Yamamoto: Research into methods of constructing data exchange standards for construction machinery, 31st Japan Society of Civil Engineers information use technical proceedings, October 2006 (submitted)

[3] Toshiyuki Kamei, Hiroshi Yamamoto: Establishment of standards for data exchange in the control stage during construction, 30st Japan Society of Civil Engineers information use technical proceedings, pp. 49-52, October 2005. 